\title{
Gambaran Pengetahuan Suami Tentang Penggunaan Kontrasepsi Vasektomi Di Desa Pingaran Ilir Kecamatan Astambul Kabupaten Banjar
}

\author{
Description of Husband knowlegde about usage of vasectomy contraception \\ in Pingaran Ilir village regency of Banjar \\ Sadirah Hanim*, Norzarimah \\ Akademi Kebidanan YAPKESBI Banjarbaru \\ Jl. Trikora (Depan Mesjid Agung Al-Munawarrah) Banjarbaru \\ *Korespondensi : sadirah.yapkesbi@gmail.com
}

\begin{abstract}
Family planning is one of the way to improve reproductive health by using contraceptives. However, participation by men in use of contraception is low. In the village of Pingaran llir there is no data of husband participating in the use of contraceptives. This can be caused to the level of knowledge and ability of husband are low to family planning. The purpose this stdy to find out know Husband's level of knowledge to vasectomy contraception in the village Pingaran llir rt 02 district Astambul regency of Banjar. Type of study used is descriptive research. Sampling technique in this study is purposive sampling with sample of 48 husbands. The research was conducted of March-April 2018 by using questionnaire instrument. The result of the research on the description of husband's knowledge level on the use of vasectomy contraception in the village Pingaran Ilir rt 02 conditioned district Astambul regency of Banjar as follows: good knowledge as much as 3 people $(6,2 \%)$, enough knowledge as much as 19 people (39,6\%) less knowledge as much as 26 people $(54,2 \%)$. Based on the above conclusions, it is necessary to make afforts to improve the better service.
\end{abstract}

Keywords : Knowledge of Husband, Vasectomy

\section{Pendahuluan}

Program keluarga berencana (KB) dibentuk dengan tujuan untuk mengendalikan jumlah penduduk sehingga dapat mewujudkan penduduk. Keberadaan program KB sebenarnya dapat membantu pasangan suami istri atau PUS untuk memperoleh jumlah anak yang dikehendaki, mengatur jarak dan waktu kelahiran serta mengantisipasi kehamilan yang tidak diinginkan (KTD), dengan memanfaatkan atal, obat dan metode kontrasepsi (1)

Pengguna KB secara nasional didominasi oleh suntik $(64,68 \%)$, disusul pil $(27,19 \%)$, Metode Kontrasepsi Jangka Panjang (MKJP) sebesar 7,06\% terdiri dari Intrauterine Device (IUD) (3,06\%), implant $(2,21 \%)$, Metode Operasi Wanita (MOW) $(1,49 \%)$ dan Metode Operasi Pria (MOP) $(0,3 \%)$ pengguna kondom sebanyak $(0,52 \%)(2)$.

Pengguna KB di Kalimantan Selatan pun masih mengandalkan kontrasepsi suntik $(59,57 \%)$ dan pil $(20,71 \%)$ dan total pengguna KB. Sedangkan persentase pengguna Metode KB Jangka Panjang (MKJP) terbesar adalah IUD $(7,03 \%)$ dan implant $(6,21 \%)$. Adapun peserta KB pria yang ada hanya mencapai sekitar $1,27 \%$ $(\mathrm{MOP}=0,27 \%$ dan kondom (1\%) (2).

Pengguna KB di Banjarbaru didominasi oleh suntik yaitu $(64,68 \%)$, disusul dengan pil $(27,19 \%)$, pengguna MKJP sebesar $(7,06 \%)$ yang terdiri dari IUD (3,06\%) implant (2,21\%), MOW $(0,52 \%)$, MOP $(0,3 \%)$, kondom $(0,52 \%)$, kondom wanita $(0,04 \%)$, pantang berkala $(0,31 \%)$, dan metode lainnya $(0,21 \%)$.

Rendahnya pengguna KB pria salah satunya karena kurangnya pengetahuan suami tentang kontrasepti vasektomi. Hasil penelitian Wahyun (2013) akseptor $\mathrm{KB}$ pria yang memiliki pengetahuan tinggi tentang vasektomi memiliki kemungkinan untuk ikut berpartisipasi dalam vasektomi sebesar 9,358 kali lebih besar daripada 
akseptor KB pria yang memiliki pengetahuan rendah (3)

Berdasarkan studi pendahuluan di Desa Pingaran Ilir RT 02 kecamatan Astambul Kabupaten Banjar dengan jumlah penduduk 323 jiwa. Jumlah PUS sebanyak 36 pasang di peroleh data bahwa pengguna KB pil sebanyak 9 orang, pengguna KB suntik 28 orang dan tidak ada yang menggunakan vasektomi.

Berdasarkan latar belakang diatas, maka peneliti merumuskan masalah sebagai berikut : " Bagaimana tingkat pengetahuan suami tentang kontrasepsi vasektomi di Desa Pingaran Ilir RT 02 Kecamatan Astambul Kabupaten Banjar Tahun 2018

\section{Metode Penelitian}

Desain penelitian yang digunakan adalah desain penelitian non eksperimen atau metode deskriptif yaitu penelitian yang bertujuan untuk mendeskriptifkan, memaparkan/menggambarkan peristiwaperistiwa yang terjadi masa kini (4).

Desain penelitian deskriptif bertujuan untuk menerangkan atau menggambarkan masalah penelitian yang terjadi berdasarkan karakteristik tempat, waktu, umur, jenis kelamin, pekerjaan, status perkawinan, cara hidup, dan lainlain (5). Penelitian ini menggambarkan tingkat pengetahuan pria tentang metode kontrasepsi vasektomi pada pria di Desa Pingaran llir RT 02 kecamatan Astambul.

\section{Hasil Penelitian}

Pendidikan Responden

Tabel 1 Distribusi Frekuensi Pendidikan Responden di Desa Pingaran Ilir Kecamatan Astambul Tahun 2018

\begin{tabular}{lcc}
\hline Pendidikan & $\mathbf{f}$ & Persentase (\%) \\
\hline Tidak tamat SD & 4 & 8,3 \\
Tamat SD & 20 & 41,7 \\
Tamat SLTP & 14 & 29,2 \\
Tamat SLTA & 9 & 18,7 \\
Tamat & 1 & 2,1 \\
DIII/IV/S1/S2 & & 100 \\
\hline Jumlah & 48 &
\end{tabular}

Pekerjaan Responden

Tabel 2 Distribusi frekuensi Pekerjaan Responden di Desa Pingaran Ilir Kecamatan Astambul Tahun 2018

\begin{tabular}{lcc}
\hline Pekerjaan & f & $\begin{array}{c}\text { Persentase } \\
(\%)\end{array}$ \\
\hline Buruh & 31 & 64,6 \\
Swasta & 16 & 33,3 \\
PNS & 1 & 2,1 \\
\hline Jumlah & 48 & 100 \\
\hline
\end{tabular}

Umur Responden

Tabel 3 Distribusi Frekuensi Umur Responden di Desa Pingaran Ilir Kecamatan Astambul Tahun 2018

\begin{tabular}{ccc}
\hline Umur & $\mathbf{f}$ & $\begin{array}{c}\text { Persentase } \\
\%\end{array}$ \\
\hline $20-30$ & 8 & 16,7 \\
$31-40$ & 28 & 58,3 \\
$\geq 41$ & 12 & 25,0 \\
\hline Jumlah & 48 & 100 \\
\hline
\end{tabular}

Pengetahuan Responden

Tabel 4. Distribusi Frekuensi Pengetahuan Suami Tentang Penggunaan Kontrasepsi Vasektomi di Desa Pingaran llir Kecamatan Astambul Tahun 2018.

\begin{tabular}{lcc}
\hline Pengetahuan & $\mathbf{f}$ & $\begin{array}{c}\text { Persentase } \\
\%\end{array}$ \\
\hline Baik & 3 & 6,2 \\
Cukup & 19 & 39,6 \\
Kurang & 26 & 54,2 \\
\hline Jumlah & 48 & 100 \\
\hline
\end{tabular}

Berdasarkan tabel 4 pengetahuan suami tentang metode kontrasepsi vasektomi pada pria dengan pengetahuan baik sebanyak 3 orang $(6,2 \%)$ cukup sebanyak 19 orang ( $39,6 \%)$ dan kurang sebanyak 26 orang $(54,2 \%)$.

\section{Pembahasan}

Berdasarkan tabel 4 diketahui bahwa dari 48 responden berpengetahuan kurang sebannyak 26 responden (54,2\%) berpengetahuan cukup sebannyak 19 responden (39,6\%) dan berpengetahuan baik sebanyak 3 responden $(6,2 \%)$.

$$
\text { Menurut Notoatmodjo }
$$
pengetahuan merupakan hasil dari tahu dan ini setelah orang melakukan pengindraan terhadap objek tertentu. Pengindraaan terjadi melalui panca indra manusia, yakni indra penglihstsn, pendengaran, penciuman, rasa dan raba. Tingkah laku manusia merupakan hasil dari pengetahuan. Jika pengetahuan baik, 
maka seseorang akan bertingkah lebih baik dan langgeng.

$$
\text { Responden yang memiliki }
$$

pengetahuan baik sebanyak 3 responden

$(6,2 \%)$, dipengaruhi oleh tingkat pendidikan. Sebanyak 2 responden tersebut pendidikan terakhir adalah SMA dan 1 responden berpendidikan terakhir Perguruan Tinggi. Tingkat pendidikan yang tinggi akan berpengaruh pada penerimaan hal-hal baru dan dapat menyesuaikan diri dengan hal baru tersebut (6).

Dari pengetahuan cukup pada 19 responden (39,6\%), sebagian besar penduduk pendidikan terakhir dasar (SD dan SLTP). Meski telah mendapat dan mempunyai pengetahuan yang cukup tentang penggunaan kontrasepsi vasektomi sebagian besar responden menganggap bahwa kontrasepsi hanyalah untuk perempuan (istri) saja.

Responden yang memiliki pengetahuan kurang sebanyak 26 orang $(54,2 \%)$, disebabkan karena 4 responden tersebut tidak tamat sekolah, 20 responden pendidikan terakhir SD dan 2 responden pendiidkan terkhir SMP. Menurut Notoatmodjo (2015), pendidikan merupakan upaya berprilaku dengan cara himbauan, ajakan, memberikan informasi dan memberikan kesadaran pada sekelompok orang. Proses pendidikan mencakup pengembangan pengetahuan, sikap dan tindakan. Sehingga semakin tinggi tingkat pendididkan semakin tinggi pula pengetahuan yang dimiliki (6).

Semakin tinggi tingkat pendidikan seseorang, semakin mudah menerima informasi sehingga semakin banyak pula pengetahuan yang dimilikinya. Dengan pendidikan tinggi maka seseorang akan cenderung untuk mendapatkan informasi, baik dari orang lain maupun media masa (6).

Menurut Nursalam dan Pariani seseorang yang mempunyai pekerjaan akan mempunyai lebih banyak informasi dan pengalaman. Dengan adanya pekerjaan seseorang mempunyai banyak waktu untuk mendapat informasi yang diperoleh baik dari media maupun dari temannya, sehingga informasi yang diperoleh semakin banyak dan pengetahuan yang dimiliki lebih tinggi (7).
Pengetahuan responden yang kurang tentang vasektomi dikarenakan informasi mengenai kontrasepsi vasektomi masih kurang dan masih awam terhadap metode kontrasepsi vasektomi tersebut. Kurangnya informasi responden dikarenakan jarang mendengarkan konseling penyuluhan yang diberikan tenaga kesehatan. Informasi dapat diperoleh melalui media masa seperti televisi, radio, surat kabar, majalah dan lain-lain.

Vasektomi adalah prosedur klinik untuk menghentikan kapasitas reproduksi pria dengan jalan melakukan okulasi vas deferensial sehingga alur transportasi sperma terhambat dan proses fertilasi tidak terjadi. Tujuan dari kontrasepsi vasektomi adalah untuk mengakhiri kesuburan. Keuntungan dari vasektomi antara lain lebih efektif, aman, morbiditas rendah, sederhana, cepat dan biaya rendah (9)

Dari hasil penelitian ini didapat bahwa tingkat pengetahuan tentang penggunaan kontrasepsi vasektomi di Desa Pingaran Ilir Kecamatan Astambul Kabupaten Banjar yang paling banyak adalah kategori kurang sebanyak 26 responden (54,2\%).

Sejalan dengan hasil penelitian yang dilakukan oleh Nurita tahun 2012 menunjukkan dari 98 orang suami yang tidak menggunakan vasektomi di Kecamatan Rancaekek yang berjumlah 98 orang, didapatkan gambaran keseluruhan mengenai pengetahuan terhadap penggunaan kontrasepsi vasektomi yaitu dalam kategori kurang (46\%) (9). Didukung pula dengan hasil penelitian Sari di tahun 2015 menunjukkan pengetahuan tentang kontrasepsi vasektomi diwilayah kerja di Puskesmas Rawasari menunjukkan 69 (72\%) responden memiliki pengetahuan rendah dan 27 (28\%) responden memiliki pengetahuan tinggi (10)

Keterlibatan pria di definisikan sebagai partisipasi dalam proses pengambilan keputusan dalam $\mathrm{KB}$, pengetahuan pria tentang $\mathrm{KB}$ dan penggunaan kontasepsi pria. Keterlibatan pria dalam KB diwujudkan melalui perannya berupa dukungan terhadap KB dan penggunaan alat kontrasepsi serta 
merencanakan jumlah anak. Penggunaan metode kontrasepsi pria merupakan satu bentuk partisipasi pria secara langsung, sedangkan keterlibatan pria secara tidak langsung misalnya pria memiliki sikap yang lebih positif dan membuat keputusan yag lebih baik berdasarkan sikap dan persepsi, serta pengetahuan yang dimilikinya (11).

Rendahnya partisipasi pria dalam KB Vasektomi disebabkan oleh dua faktor utama, yaitu faktor dukungan baik politis, sosial budaya, maupun keluarga yang masih rendah sebagai akibat rendah / kurangnya pengetahuan pria atau suami serta lingkungan sosial budaya yang menganggap KB dan kesehatan reproduksi merupakan urusan dan tanggung jawab perempuan, faktor akses baik akses informasi, maupun akses pelayanan (12).

Pengetahuan suami tentang penggunaan kontrasepsi vasektomi perlu ditingkatkan karena dengan mengetahui tentang kontrasepsi vasektomi dapat lebih berpartisipasi dalam program KB, sehingga dapat meningkatkan cakupan $\mathrm{KB}$ vasektomi.

\section{Kesimpulan}

Pengetahuan suami tentang metode kontrasepsi vasektomi pada pria dengan pengetahuan baik sebanyak 3 orang $(6,2$ $\%)$ cukup sebanyak 19 orang ( $39,6 \%)$ dan kurang sebanyak 26 orang $(54,2 \%)$.

\section{Saran}

a. Bagi Peneliti Selanjutnya

Disarankan bagi peneliti lain yang tertarik untuk melanjutkan penelitian ini agar dapat memiliki lebih lanjut dengan mencari variabel lain yang berhubungan dengan metode kontrasepsi vasektom

b. Bagi Responden

Disarankan bagi responden setelah mengetahui tentang metode kontasepsi vasektomi para suami berniat untuk menggunakan metode tersebut.

\section{Daftar Pustaka}

1. WHO. Tujuan dari Program Keluarga Berencana (KB) Word Heart Organication: [Cited 23 April 2018]. Available from: http://www.who.go.id/tujuan.kb tahun2015.10April2018

2. BKKBN. Cara-cara Kontrasepsi Yang digunakan Dewasa. 2015. [Cited 23 April 2018]. Available from: http://www.bkkbn.go.id/data/dokumen/ pengguna/kb.tahun2015 10April2018

3. Wahyuni, dkk. Hubungan pengetahuan dan sikap akseptor kb pria tentang vasektomi serta dukungan keluarga dengan partisipasi pria dalam vasektomi (di kecamatan tejakula kabupaten buleleng). Jurnal Magister Kedokteran Keluarga, 1 (1). pp. 80-91. [Cited 5 April 2018]. Available from: https://eprints.uns.ac.id/2148/1/231433-1-SM.pdf

4. Nursalam. Konsep dan Penerapan Metologi Penelitian Keperawatan. Jakarta: Info Medika: 2015

5. Hidayat, Alimul. Kesehatan Reproduksi dan Keluarga Berencana. Jakarta: EGC: 2014

6. Notoatmodjo, S. Pendidikan dan Prilaku Kesehatan. Jakarta: Rineka Cipta: 2015

7. Nursalam, Pariani. Ajar Kependudukan dan Pelayanan KB. Jakarta: Info Mediaka: 2014

8. Saefudin, A. B. Buku Acuan Nasional Pelayanan Kesehatan Maternal dan Kesehatan. Jakarta: JNPKKR POGI dan Yayasan Bina Pustaka Sarwono Prawiroharjo: 2016

9. Nurita, dkk. Pengetahuan dan sikap suami terhadap kontrasepsi mantap vasektomi di Kecamatan Rancaekek. Students EJournalis. Volume 1, No 1, 2012 [Cited 7 April 2018]. Available from:

http://jurnal.unpad.ac.id/ejournal/articl e/view/687/733

10. Sari, Ratna . Nurfiriani. Gambaran pengetahuan dan sikap pria produktif terhadap metode kontrasepsi vasektomi di wilayah kerja Puskesmas Rawasari. Jurnal 
Akademika Baiturrahim. Vol.5, No.1, Maret 2016. [Cited 7 April 2018]. Available from: http://stikba.ac.id/medias/journal/1418.pdf

11. BKKBN. Peningkatan Partisipasi Pria dalam KB dan KR, Jakarta : BKKBN. 2005.

12. Sulistyawati, A. Pelayanan Keluarga Berencan. Salemba Medika. Jakarta : 2013 